\title{
ANALISIS FRAMING PEMBENTUKAN CITRA SOEMARMO HADI SAPUTRO MENJELANG PEMILIHAN WALIKOTA SEMARANG TAHUN 2015 DI MEDIA HARIAN RAKYAT JATENG
}

\section{Airlangga Pradipta Adhitama}

(airlangga549@yahoo.co.id)

(Alumni S1 Program Studi Ilmu Komunikasi Universitas Semarang)

\begin{abstract}
Soemarmo Hadi Saputro elections in Semarang in 2015 that was held in December to invite the attention of the mass media. How the People's Daily Java Soemarmo image framing events in the news ahead of Election 2015. This study aims to determine how the media in reporting the People's Daily Java Soemarmo as a candidate for mayor using the structure of syntax, script, thematic and rhetorical. This study used a qualitative descriptive Metode framing analysis techniques with models developed by Pan and Gerald Zhongdhang M.Kosicki. The results of analysis of this study is the People's Daily Java-related news framing Soemarmo as a candidate for mayor of Semarang to prioritize the elements of persona and the elements of what. Although the news framing Soemarmo forward the elements of who and what, the People's Daily Java still show neutrality and objectivity in reporting to display items of news by displaying completeness $5 \mathrm{~W}+1 \mathrm{H}$.
\end{abstract}

Kata Kunci : Framing Pan dan Kosicki, Citra Soemarmo, Pilkada

\section{Pendahuluan}

Tanggal 9 Desember 2015 merupakan hari puncak pelaksaanaan Pemilihan Kepala Daerah Kota Semarang. Menjelang Pemilihan Kepala Daerah Kota Semarang 2015, pemberitaan mengenai pemilihan Walikota Semarang mendapatkan perhatian yang cukup besar dari masyarakat dengan tiga pasang kandidat yang mencalonkan diri, yaitu Soemarmo Hadi Saputro-Zuber Safawi, Hendrar Prihadi (Hendi)Heveartita Gunaryanti (Ita), dan Sigit Ibnugroho Sarasprono-Agus. Dari ketiga pasangan calon Walikota dan Wakil Walikota Semarang tersebut, terdapat satu calon kandidat walikota yang memiliki citra buruk di mata publik yaitu Soemarmo Hadi Saputro. Pasalnya mantan Walikota Semarang ini merupakan mantan narapidana dengan kasus korupsi terkait dana APBD tahun 2012.

Tentu saja ini sangat berpengaruh besar terhadap pencalonannya yang kedua kalinya sebagai calon Walikota Semarang tahun 2015, karena image personal Soemarmo di tengah masyarakat Kota Semarang sudah identik sebagai pemimpin kepala daerah yang koruptor.

Selain sebagai mantan narapidana dengan kasus korupsi, pemberitaan Soemarmo di media Harian Rakyat Jateng digambarkan 
sebagai sosok figur yang merakyat dan mengerti apa yang dikeluhakan masyarakat dan tidak semata mata Harian Rakyat Jateng menunjukkan Soemarmo sebagai calon yang mempunyai citra buruk di masa lalu atau memberitakan rekam jejaknya yang buruk secara terus menerus ketika tersangkut masalah hukum dengan kasus korupsi. Hal ini dapat dilihat dari pemberitaan Soemarmo di Media Harian Rakyat Jateng edisi 11 November 2015 dengan judul "Marmo Berdayakan Perempuan Nelayan Dengan Keterampilan”, dan edisi 19 November 2015 dengan judul "Lima Komitmen Marmo Bangun Pasar Tradisional".

Persaingan untuk memperebutkan hati dan perhatian masyarakat tidak dapat dilakukan sendiri oleh partai politik dan kontestan. Untuk melakukannya, mereka membutuhkan media dan pers. Dengan menggunakan media dan pers, cakupan (coverage) penyebaran informasi, program kerja, dan produk politik lainnya akan menjadi lebih efektif. Dengan kata lain penyebarannya akan menjadi lebih luas dan komprehensif (Firmanzah, 2007: 62). Hal ini membuat partai politik dan calon individu harus bekerja keras dengan media dan pers. Sementara media dan pers membutuhkan berita dan informasi sebagai produk mereka yang bisa diperoleh dari partai politik. Partai politik dan calon individu membutuhkan bantuan media dan pers dalam memperebutkan hati rakyat.

Saluran komunikasi politik sangat beragam, pada dasarnya saluran komunikasi politik sama dengan saluran komunikasi secara umum. Saluran komunikasi politik adalah alat atau sarana yang memudahkan penyampaian pesan politik. Saluran komunikasi politik tidak hanya mencakup alat, sarana dan mekanisme seperti mesin cetak, radio, televisi dan sebagainya, tetapi yang paling penting adalah manusia itu sendiri. Manusia sebagai otak perumusan pesan politik melalui sarana yang ada di media massa (Dan Nimmo, 2001:166). Oleh karena itu manusia sebagai aktor politik memanfaatkan media massa untuk menyebarluaskan pembicaraan pembicaraan politik ataupun informasi seputar politik dengan untuk mencapai tujuan politiknya lebih besar daripada melalui saluran komunikasi politik yang lain.

Media merupakan saluran penyampaian pesan dalam komunikasi antarmanusia. Menurut McLuhan media massa adalah perpanjangan alat indra kita. Melalui media massa kita memperoleh informasi tentang benda, orang, atau tempat yang tidak kita alami secara langsung (Firsan Nova, 2009:204).

Selanjutnya, penelitian ini memilih media Harian Rakyat Jateng sebagai subjek penelitian karena Harian Rakyat Jateng merupakan media lokal Jawa Tengah yang dalam menyajikan informasi berita lebih mengutamakan berita politik, ekonomi, hiburan dan hukum. Sebagai media massa yang berbasis berita politik tentunya akan menjadi penilaian masyarakat dalam menyajikan informasi seputar berita politik. Apalagi di musim Pilkada, Harian 
Rakyat Jateng yang tergolong sebagai media massa baru di wilayah Jawa Tengah akan di uji dan menjadi sorotan masyarakat tentang pemberitaan seputar Pilkada. Sebuah ujian bagi media yang tergolong baru adalah apakah media dengan basis menyajikan berita politik bisa memberikan informasi yang obyektif dan berimbang dengan adanya tiga pasangan calon kandidat yang dalam Pilkada 2015, atau dengan adanya Pilkada, media ini lebih memanfaatkan beberapa tokoh politik atau kandidat calon pasangan walikota yang bermain di balik layar untuk mengembangkan media Harian Rakyat Jateng yang merupakan media baru.

\section{Pembahasan}

Konsep framing Pan dan Kosicki yaitu sebagai proses pembuatan suatu pesan lebih menonjol, menempatkan informasi lebih daripada yang lain sehingga khalayak lebih tertuju pada pesan tersebut.

Menurut Pan dan Kosicki, ada dua konsepsi dari dari framing yang saling berkaitan, yaitu :

1) Konsepsi psikologi yakni menekankan pada bagaimana seseorang memproses informasi pada dirinya yang berkaitan dengan struktur kognitif dalam mengolah informasi dan ditunjukan dalam skema tertentu. Framing dilihat sebagai penempatan informasi dalam suatu konteks yang unik/khusus dan menempatkan elemen tertentu dari suatu isu dengan penempatan lebih menonjol dalam kognisi seseorang.
2) Konsepsi sosiologis lebih melihat pada bagaimana konstruksi sosial pada realitas. Frame disini berfungsi melihat membuat suatu realitas menjadi teridentifikasi, dipahami, dan dapat dimengerti karena sudah dilabeli dengan label tertentu (Eriyanto, 2002: 252).

Model ini berasumsi bahwa setiap berita mempunyai frame yang berfungsi sebagai pusat dari organisasi ide. Frame adalah suatu ide yang dihubungkan dengan elemen yang berbeda dalam teks berita (seperti kutipan sumber, latar informasi, pemakaian kata atau kalimat tertentu) ke dalam teks secara keseluruhan. Frame berhubungan dengan makna yang berdasarkan perangkat tanda dimunculkan dalam teks sehingga seseorang dapat memaknai suatu peristiwa. Perangkat framing dalam pendekatan ini dapat dibagi dalam empat struktur besar :

\section{Sintaksis}

Struktur sintaksis berhubungan dengan bagaimana jurnalis menyususn peristiwa, pernyataan, opini, kutipan, dan pengamatan atas peristiwa ke dalam susunan umum berita. Dalam hal ini sintaksis berusaha mengkaji hubungan tanda-tanda dan bagaimana cara tanda bekerjasama untuk menjalankan fungsinya. Keberadaan struktur sintaksis ini dapat dilihat dengan mengamati bagan sebuah berita yang meliputi headline, lead yang dipakai, latar kutipan yang diambil. Skema berita adalah perangkat framing dari struktur sintaksis yang mempunyai beberapa bagian. Bagian dari sintaksis tersebut adalah (Adnan Hussein, 2012:127) : 
* Headline

Headline atau judul berita, yang merupakan aspek sintaksis dari wacana berita dengan tingkat kemenonjolan yang tinggi dan menunjukan kecenderungan berita yang diangkat. Berkaitan dengan judul berita, biasanya judul berita dibuat semenarik mungkin.

* Lead

Lead merupakan pengantar sebelum masuk ke dalam isi berita. Lead bisa menjadi penjelas headline dan bisa juga menggambarkan latar berita. Fungsi lead dalam framing berita adalah memberikan sudut pandang berita dan perspektif tertentu dari peristiwa yang diberitakan.

\section{* Latar}

Latar merupakan bagian dari berita yang dapat digunakan sebagai alasan pembenar gagasan yang diajukan dalam suatu teks. Latar peristiwa dipakai untuk menyediakan latar belakang kemana teks berita hendak diarahkan.

\section{* Kutipan}

Penulisan kutipan sumber bertujuan untuk membangun objektivitas. Kutipan pun dipakai untuk menjelaskan bahwa apa yang ditulis berita bukan sekedar pendapat wartawan, melainkan pendapat dari narasumber.

\section{Skrip}

Bentuk umum dari unsur penulisan berita atau skrip adalah pola $5 \mathrm{~W}+1 \mathrm{H}$ (Who, What, When, Where, Why, dan How). Meskipun pola ini tidak selalu dapat dijumpai dalam berita yang ditampilkan, kategori informasi ini diharapkan diambil oleh wartawan untuk dilaporkan. Unsur kelengkapan berita ini dapat menjadi pertanda framing yang ingin ditampilkan. (Adnan Hussein, 2011: 130)

1. Tematik

Tematik merupakan proses pengaturan tekstual yang disuguhkan kepada pembaca sehingga pembaca dapat memberikan perhatian pada bagian-bagian terpenting dari isi teks. Sebuah tema bukan merupakan hasil dari seperangkat elemen yang spesifik melainkan berhubungan dengan bagaimana fakta itu ditulis. Dalam suatu peristiwatertentu, pembuat teks dapat melakukan rekayasa penafsiran pembaca/khalayak tentang suatu peristiwa. Elemen dari struktur skrip adalah (Adnan Hussein, 2011:130) :

\section{* Detail}

Elemen yang berelasi dengan kontrol informasi yang ditampilkan seseorang (komunikator). Komunikator akan menampilkan secara berlebihan informasi yang menguntungkan dirinya atau citra yang baik. Sebaliknya ia akan menampilkan informasi dalam jumlah sedikit (bahkan bila perlu tidak disampaikan) jika hal itu merugikan kedudukannya. Dalam analisis framing, kita bisa melihat bagaimana jurnalis menampilkan informasi secara lebih banyak daripada informasi yang lain.

\section{* Koherensi}

Koherensi dipahami sebagai pentaan secara rapi realitas dan gagasan, fakta, dan ide kedalam satu untaian yang logis sehingga memudahkan untuk memahami pesan yang dikandungnya. Koherensi dapat ditampilkan melalui hubungan sebab akibat dan bisa juga sebagai penjelas. Koherensi ini secara mudah dapat diamati, diantaranya dari 
kata hubung yang dipakai (dan, akibat, tetapi, lalu, karena, meskipun) menyebabkan makna yang berlainan ketika hendak menghubungkan proposisi.

\section{* Bentuk Kalimat}

Bentuk kalimat adalah sisi pemakaian kalimat yang berelasi dengan cara berfikir logis, yaitu prinsip kausalitas. Logika kausalitas ini kalau diterjemahkan kedalam bahasa menjadi susunan subjek (yang menerangkan) dan predikat (yang diterangkan). Bentuk kalimat ini tidak hanya menjadi persoalan teknis kebenaran tata bahasa, tetapi menentukan makna yang dibentuk oleh susunan kalimat.

\section{* Kata Ganti}

Kata ganti adalah elemen yang digunakan untuk melakukan manipulasi bahasa dengan membuat suatu komunitas imajinatif. Ada gejala umum dalam praktik, jurnalisme, jurnalis menggunakan kata yang berbeda dengan makna yang sama dalam konteks yang sama. Ini tidak lepas dari kaidah jurnalisme, dimana agar berita menarik, jurnalis menggunakan kata-kata yang berbeda dalam sebuah berita. namun yang perlu diperhatikan adalah kata yang berbeda walaupun bermakna sama, memiliki makna yang berbeda.

\section{Retoris}

Struktur retoris berelasi dengan bagaimana cara jurnalis memberi penekanan arti tertentu dalam berita yang disusunnya. Jurnalis menggunakan perangkat retoris untuk membangun citra, meningkatkan poinpoin yang menonjol pada sisi tertentu dan meningkatkan gambaran yang diinginkan dari suatu berita. Ada beberapa elemen struktur retoris yang dipakai oleh wartawan (Adnan Hussein, 2011:132).

\section{* Leksikon}

Elemen ini menandakan bagaimana seseorang melakukan pemilihan kata atas berbagai kemungkinan kata yang tersedia. Pilihan kata yang digunakan komunikator secara ideologis menunjukkan bagaimana pemaknaannya terhadap fakta atau realitas.

* Metafora

Metafora merupakan unsur ketiga dalam struktur retoris. Dalam berita, jurnalis bukan hanya menyusun teks saja, namun untuk menghidupkan berita, para jurnalis menuliskan pula kiasa, ungkapan, perbandingan, dan sebagainya. Secara literal, metafora dapat diartikan sebagai cara untuk memindahkan makna dengan merealisasikan dua fakta melalui analogi, atau memakai kiasan denan menggunakan kata-kata seperti, ibarat, bak, umpama dan laksana.

\section{* Grafis}

Grafis merupakan elemen wacana yang dipakai untuk memeriksa apa yang ditekankan atau ditonjolkan melalui bagian tulisan, seperti pemakaian tanda tanya, huruf tebal, miring, garis bawah, bahkan termasuk grafik, tabel dan foto.

Dalam proses pembelajaran memahami sebuah berita tentunya kita harus memahami unsur-unsur yang terdapat dalam sebuah berita. Adapun unsur-unsur berita terdiri atas what (apa), who (siapa), where (dimana), when (kapan), why (mengapa), dan how (bagaimana). Berikut penjelasan 
yang lebih lengkap mengenai unsurunsur tersebut (Inung Cahya , 2012:17) yaitu :

\section{What}

Suatu berita dikatakan baik jika memenuhi unsur what, yaitu berisi pernyataan yang dapat menjawab pertanyaan apa.

\section{Who}

Suatu berita dikatakan baik jika memenuhi unsur who, yaitu disertai keterangan tentang orang-orang yang terlibat dalam peristiwa.

\section{When}

Suatu berita dikatakan baik jika memenuhi unsur when, yaitu menyebutkan waktu kejadian peristiwa.

\section{Where}

Suatu berita dikatakan baik jika memenuhi unsur where, yaitu berisi deskripsi lengkap tentang tempat kejadian.

5. Why

Suatu berita dikatakan baik jika memenuhi unsur why, yaitu disertai alasan atau latar belakang terjadinya peristiwa.

\section{How}

Suatu berita dikatakan baik jika memenuhi unsur how, yaitu dapat dijelaskan proses kejadian suatu peristiwa dan akibat yang ditimbulkan.

Seperti tubuh kita, berita juga mempunyai bagian-bagian, diantaranya adalah sebagai berikut (Wahyu Wibowo, 2003:47) :

1. Judul berita

Berfungsi mengiklankan berita. Judul berita ditulis dengan kalimat singkat, jelas, dan mencerminkan isi pokok berita yang terangkum dalam teras berita.
2. Baris tanggal (dateline)

Mengandung dua pengertian. Pertama, tempat asal berita dan tanggal kejadian yang terletak pada bagian atas berita. Kedua, tanggal penerbitan surat kabar. 3. Teras berita (lead atau intro) Yaitu paragraf pertama dari sebuah berita yang berisi bagian paling penting atau hal yang paling menarik. Teras berita ditulis secara singkat dan padat dalam satu kalimat yang biasanya terdiri atas paling banyak 280 karakter.

4. Tubuh berita (body)

Yakni berupa uraian penjelasan dari yang sudah tertuang di Lead.

Berdasarkan analisis framing dengan menggunakan teori model Zhongdhang Pan dan Gerald M. Kosicki, ditemukan beberapa kemenonjolan berita yang mendukung pembentukan citra postif Soemarmo menjelang pemilihan Walikota Semarang 2015.

Berita pertama dengan judul "Debat Publik, KPU Kesulitan Kendalikan Massa Paslon" menunjukkkan kemenonjolan berita bagian latar informasi. Dalam latar informasi terdapat unsur Who (siapa) dan What (apa). Hal ini dapat dilihat dari ketiga pasangan calon Walikota dalam menyampaikan visi misinya berkaitan dengan pendidikan di Kota Semarang. Dalam penyampaian program kerja di bidang pendidikan, Harian Rakyat Jateng menuliskan program kerja Soemarmo lebih detail yaitu "Di bidang pendidikan Soemarmo telah menyiapkan bus gratis bagi siswa sekolah dan meningkatkan kualitas mengajar guru. Selain itu menambah sarana bermain 
bagi anak usia dini juga disampaikan olehnya". Sedangkan dari Pasangan Hendi-Ita hanya dituliskan secara umum program kerja yang akan dilaksanakan yaitu dengan mengoptimalisasi sekolah gratis dan pemerataan jumlah sekolah. Kemudian dari pasangan no urut 3 (Sigit-Agus) juga dituliskan pemaparan program kerja yang akan dilakukan secara abstrak yaitu dengan menambah pendidikan anti korupsi bagi siswa sejak dini. Detailnya latar informasi yang disajikan media ini berkaiatan dengan program kerja Soemarmo menunjukkan bahwa Harian Rakyat Jateng cenderung membangun citra positif Soemarmo dengan menonjolkan bagian latar.

Sedangkan pada sampel berita kedua pembentukan citra positif Soemarmo di Harian Rakyat Jateng terlihat dari judul, unsur what (apa) dan who (siapa). Judul yang dituliskan di Harian Rakyat Jateng "Marmo Berdayakan Perempuan Nelayan dengan Keterampilan” menggambarkan Soemarmo sebagai calon Walikota yang peduli terhadap nelayan. Penekanan pada judul yang terdiri dari unsur what dan who mengarah pada citra positif Soemarmo seakan akan mengarahkan khalayak pembaca ke opini publik ke arah yang positif. Sedangkan pada isi berita juga menekankan unsur what dan who tanpa melihat dan mencantumkan sosok Soemarmo yang mempunyai citra negatif yang tercatat sebagai mantan narapidana dengan kasus korupsi.

Kemudian untuk sampel berita yang ketiga dengan Judul "Lima
Komitmen Marmo Bangun Pasar Tradisional", penonjolan dan penekanan berita tidak jauh berbeda dengan smpel berita pertama dan kedua. Pada berita ketiga ini pembentukan citra positif Soemarmo dapat dilihat dari penekanan pada judul yang mengarahkan khalayak untuk menilai Soemarmo sebagai calon Walikota yang peduli terhadap pedagang pasar tradisional dengan cara membangun pasar melalui lima komitmen program yang disampaikan Soemarmo. Sedangkan pada isi berita, pembentukan citra positif Soemarmo juga dapat dilihat dari latar informasi yang menuliskan bahwa pembangunan pasar yang akan dilakukan Soemarmo menggunakan dana APBD dan tidak diserahkan kepada investor. Hal ini mengarahkan khalayak untuk menilai Soemarmo seakan akan memanfaatkan dan mengelola APBD dengan baik tanpa mencantumkan citra negatifnya terkait kasus korupsi dana APBD yang membawanya kedalam jeruji besi.

Secara

keseluruhan

pembentukan citra Soemarmo melalui harian Rakyat Jateng dapat dilihat dari kemenonjolan pada judul berita yang menekankan pada unsur who (siapa) dan what (apa). Unsur who dalam hal ini adalah Soemarmo. Soemarmo merupakan mantan Walikota Semarang pada periode 2010-2015, tidak sampai satu periode menjabat sebagai walikota ia dinyatakan sebagai koruptor dan menyandang status sebagai narapidana kasus korupsi. Penonjolan pada judul berita yang disajikan Harian Rakyat Jateng menekankan pada sosok Soemarmo dengan menyertakan program kerja 
yang akan dilakukan tanpa menyertakan atau menjelaskan sosok Soemarmo sebagai mantan narapidana kasus korupsi. Hal ini dapat dilihat pada berita yang disajikan berkaitan dengan pembangunan pasar tradisional di Kota Semarang dan kepedulian Soemarmo terhadap warga kampung nelayan Tambak Lorok. Judul berita berkaitan dengan pasar tradisional dituliskan dengan "Lima Komitmen Marmo Bangun Pasar Tradisional”. Judul tersebut secara otomastis mengarahkan khalayak pembaca untuk menilai Soemarmo sebagai calon walikota yang mempunyai nilai positif dan peduli terhadap pedagang pasar, tradisional mengingat sering munculnya permasalahan mengenai revitalisasi pasar tradisonal dan relokasi pedagang pasar. Hal ini dilakukan Harian Rakyat Jateng untuk membangun citra positifnya dan seakan-akan melupakan citra negatifnya dimasa lalu. Kemudian judul berita berkaitan dengan warga kampung nelayan Tambak Lorok dituliskan "Marmo Berdayakan Perempuan Nelayan Dengan Keterampilan”. Judul tersebut tujuannya tidak jauh berbeda dengan judul yang berkaitan dengan pasar tradisional yaitu untuk membangun citra positif Soemarmo. Pada judul ini sasaran mengarahkan Khalayak pembaca untuk menilai citra positifnya melalui kepeduliannya terhadapn warga kampung nelayan dengan memberikan keterampilan.

Sementara itu, kemenonjolan lain dalam membangun citra Soemarmo dapat dilihat dari isi berita yaitu pada latar. Pada bagian latar khususnya pada berita dengan judul "Debat Publik, KPU Kesulitan Kendalikan Masa Paslon", terlihat pada saat penulisan program kerja yang dipaparkan masing-masing calon Walikota Semarang. Dalam penulisannya, program kerja berkaitan dengan pendidikan, Soemarmo dituliskan secara detail mengenai pendidika dengan menyediakan fasilitas bus gratis dan meningkatkan kualitas mengajar guru. Sedangkan pada calon lain (Hendi dan Sigit) hanya dituliskan secara umum dan abstrak saja. Padahal disisi lain Soemarmo sebagai mantan narapidana, tidak dituliskan sedikitpun masalah berkaitan dengan statusnya sebagai koruptor dan tidak sedikit pun wujud permintaan maafnya kepada masyarakat ditampilkan melalui Harian Rakyat Jateng. Hal ini sebagai upaya untuk membangun citra positif mengalihkan khalayak pembaca terhadap citra negatifnya.

Harian Rakyat Jateng memberitakan sosok Soemarmo sebagai sosok yang peduli terhadap msayarakat seakan-akan bertujuan untuk meningkatkan popularitas Soemarmo melalui media dengan menampilkan program kerja yang positif demi mendapat dukungan dari khalayak pembaca untuk menentukan dan memilih Soemarmo sebagai Walikota Semarang 2015.

\section{Kesimpulan}

Berdasarkan penelitian yang telah dilakukan, dapat ditarik kesimpulan bahwa pembingkaian berita Soemarmo sebagai calon Walikota Semarang 2015 di Harian 
Rakyat Jateng menampilkan kemenonjolan usnur Who (siapa) dan unsur What (apa) pada judul berita dan latar informasi tanpa menyertakan atau menjelaskan sedikitpun statusnya sebagai mantan narapidana kasus korupsi. Kemenonjolan unsur What dan Who pada judul berita berdampak pada meningkatnya citra positif Soemarmo dalam memperoleh dukungannya melalui media Harian Rakyat Jateng Walaupun pada akhirnya dalam Pilkada Kota Semarang 2015 mendapat urutan no 2 setelah Pasangan Hendi- Ita.

Selain itu, secara keseluruhan penulisan berita berkaitan dengan pencalonan Soemarmo sebagai calon Walikota Semarang menunjukaan kelengkapan berita. Hal ini dapat dilihat dari struktur skrip yang terdapat dalam setiap berita yang terdiri dari $5 \mathrm{~W}+1 \mathrm{H}$. Penggunaan bahasa dalam menuliskan berita pun juga menggunakan bahasa yang sederhana dan mudah dimengerti.

\section{Daftar Pustaka}

Adnan Hussein. (2011). Mix Methodology dalam Penelitian Komunikasi. Jakarta: ASPIKOM

Dan Nimmo. (2001). Komunikasi Politik Khalayak dan Efek. Bandung : PT Remaja Rosdakarya

Eriyanto. (2002). Analisis Framing: Konstruksi, Ideologi, dan Politik Media. Yogyakarta: LkiS.

Firmanzah. (2007). Marketing Politik. Jakarta: Yayasan Obor.
Firsan Nova. (2009). Crisis Public Relation. Jakarta: Gramedia.

Inung Cahya . (2012). Menulis Berita di Media Massa. Yogyakarta : PT. Citra Aji Parama.

Wahyu Wibowo. (2003). Manajemen bahasa pengorganisasian karangan pragmatic dalam bahasa indionesia untuk mahasiswa dan praktisi bisnis. Jakarta : Gramedia Pustaka Utama. 